\title{
Development of Customized Corrugated Fibre Board Boxes for Sapota Packaging
}

\author{
S. Bhuvaneswari ${ }^{*}$ and D.V. Sudhakar Rao
}

Division of Post-Harvest Technology and Agricultural Engineering, ICAR-Indian Institute of Horticultural Research, Hessaraghatta Lake (PO), Bengaluru-560 089, Karnataka, India

*Corresponding author

\section{A B S T R A C T}

Keywords

Sapota, Customised

corrugated fibre board

box, Drop test, Shelf life,

Spoilage

Article Info

Accepted:

24 February 2018

Available Online:

10 March 2018
Sapota (cv: Cricket Ball) harvested from farmers field, packaged in customized Corrugated Fibre Board box of size $400 \times 300 \times 100 \mathrm{~mm}$, 5ply rate, 180GSM kraft paper thickness with $20 \mathrm{BF}$ bursting strength withstood drop test as compared CFB boxes made from other combinations. These CFB boxes had less cobb value $\left(12.42 \mathrm{~g} / \mathrm{m}^{2}\right)$ and puncture resistance $\left(82.86 \mathrm{~N} / \mathrm{m}^{2}\right)$ compared to other boxes. The sapota fruits packaged and stored in these boxes had a shelf life of 16 days at low temperature storage $\left(18^{\circ} \mathrm{C}, 80 \% \mathrm{RH}\right)$ and 6 days at ambient storage condition $\left(28-30^{\circ} \mathrm{C}, 55 \%\right.$ $\mathrm{RH})$.

\section{Introduction}

Sapota (Manikera zapota L.) is a tropical fruit. It is highly perishable and reduces the marketability which includes bruising damage and mechanical damage such as abrasion and puncture injuries which are more during handling and transportation. Farmers select the cheapest and the most readily available packages. Other packaging materials like mesh bags, sacks or baskets are unacceptable for sapota transport due to high susceptibility to bruising.

The impact during transportation is the main reasons to cause packages to be damaged. The fruits and vegetables packages come under impact, vibration, dropping, swinging, static pressure and many other factors in storage and transportation with the result of damaged fruits and vegetables. In order to prevent the sapota from bruising damage proper packaging is needed

Corrugated fibre boxes as packaging material have many advantages such as light weight, low cost, are easy to design, process and print and reduce mechanical damage. The empty box can be folded up, compact and is easy to be transported and stored and also they are easy to recycle, non-polluting and reusable.

A transportation packaging test is important to determine the highest normal strains that will 
occur during a transport. The test conducted the structure and quality of a corrugated board is essential to ensure the protection of the product during dropping. During storage and transportation, products can fall onto the floor resulting in damage, and a drop test is used to determine the box's ability to retain and protect its contents under a shock due to a free fall (Djilali Hammou et al., 2012).

The present study was undertaken with an objective to evaluate the suitability of Corrugated Fibre Board (CFB) boxes to withstand drop test and in retaining the sapota fruit quality during subsequent storage drop test.

\section{Materials and Methods}

Raw Material: Sapota harvested from the farmers field, after cleaning was taken for packaging and storage studies.

Development of Corrugated Fibre Board (CFB) Box: CFB boxes of size $400 \times 300 \times 100 \mathrm{~mm}$ with capacity $3.5-4 \mathrm{~kg}$ with kraft paper of thickness 200GSM and bursting strength 18,20 and $22 \mathrm{~kg} / \mathrm{cm}^{2}$ for 3 ply rate box as well as 5 ply rate box of size 400X300X100mm with kraft paper thickness 180 GSM and bursting strength 18, 20, 22 $\mathrm{kg} / \mathrm{cm}^{2}$ with B flute was designed and fabricated for packaging and storage of sapota.

Sapota (Cv. Cricket Ball) (approx.3.5-4kg) were packed in the boxes in various treatment combinations T1-(5ply, 180GSM, 18BF), T2(5ply, 180GSM, 20BF), T3-(5ply, 180GSM, 22BF), T4-(3ply, 200GSM, 18BF), T5-(3ply, 200GSM, 20BF), T6-(3ply, 200GSM, 22BF). The boxes with sapota were then stored at low temperature $\left(15^{\circ} \mathrm{C}, \mathrm{RH} 85 \%\right)$ and ambient temperature $\left(26^{\circ} \mathrm{C}, \mathrm{RH} 46.2 \%\right)$.

Testing of Corrugated Fibre Board Boxes for sapota packaging
Drop Test: This test stimulates actual shocks by dropping the package and its content freely against a rigid plane surface from a predetermined height.

For example, a drop test can be conducted so that the package hits the surface diagonally against one corner (ISO 2248). The boxes packed with sapota were subjected to drop test from a height of about $1 \mathrm{~m}$ from the ground level.

Puncture resistance: Reflects the strength of paper. It is more relevant in case of 5-ply and 7-ply. It determines the resistance of corrugated boards to external forces (IS 13228:2006).

Cobb value: A measure of how much water the paper will absorb in given time, say, one minute. This property gives the extent of loss of strength of corrugated fibre board box due to high humidity especially in low temperature storage (IS 13228:2006).

Weight of water, $\frac{g}{\mathrm{~m} 2}=$ final weight $(g)-\operatorname{conditioned~weight~}(g)$

\section{Storage Studies of sapota in customised corrugated fibre board box}

The sapota fruits packaged in CFB boxes after subjecting to drop testing were stored in ambient condition $\left(28-30^{\circ} \mathrm{C}, 55 \% \mathrm{RH}\right)$ and low temperature storage $\left(18^{\circ} \mathrm{C}, 80 \% \mathrm{RH}\right)$

The sapota samples in storage (both ambient and low temperature) were subjected to the quality analysis as follows.

\section{Weight loss}

Weight loss of fruits was calculated from the initial weight sapota fruit per treatment and at each storage interval of 2 days during storage period. 


\section{Total soluble solids}

The total soluble solids (TSS) were determined by placing an aliquot of the juice which was obtained from the flesh of papaya and was homogenized in a laboratory blender. Two drops of clear juice was placed on the prism of digital hand held refractrometer (ERMA ${ }^{\mathrm{TM}}$ ) with a range of 0 to $32^{\circ} \mathrm{Brix}$ and resolution of $0.2^{\circ}$ Brix. The refractrometer was standardized against distilled water (0\% TSS).

\section{Titrable acidity}

For titratable acidity (TA) determination, papaya juice was extracted from the sample with a juice extractor and filtered with filter paper. Clear juice was used for the analysis of TA as the methods described by Ranganna (2000). The TA expressed as percent citric acid, was obtained by titrating $10 \mathrm{ml}$ of papaya juice to $\mathrm{pH} 8.2$ with $0.1 \mathrm{~N} \mathrm{NaOH}$.

\section{Reducing and total sugars}

Reducing and total sugars were estimated by Lane and Eynon method. The sugar content in the fruit sample is estimated by determining the volume of the sugar solution (unknown) required to completely reduce a measured volume of Fehlings solution (Ranganna, 2000).

\section{Statistical analysis}

Difference between the treatments was determined by analysis of variance (ANOVA) in completely randomized design with three replications using WASP 2.0 statistical software (Bhuvaneswari and Narayana, 2013).

\section{Results and Discussion}

Physical properties of corrugated fibre board boxes for sapota packaging.
The customised CFB boxes designed with different thickness and bursting strength combination viz., T1- (5ply, 180GSM, 18BF), T2- (5ply, 180GSM, 20BF), T3-(5ply, 180GSM, 22BF), T4-(3ply, 200GSM, 18BF), T5-(3ply, 200GSM, 20BF), T6- (3ply, 200GSM, 22BF). The boxes were tested for Cobb value $\mathrm{g} / \mathrm{m}^{2}$ (water absorption) and tear resistance. The cobb value of the boxes ranged from $6.42-16.21 \mathrm{~g} / \mathrm{m}^{2}$ (Table 1). The cobb value (water absorption) was lesser for the treatment T4 as compared to treatment 5 and treatment 6 . This showed that the CFB box of $18 \mathrm{BF}$ strength has more water absorption capacity than with 20 and 22BF strength. The puncture resistance of CFB boxes ranged from 117-132.33ounzeinch/tear inch (Table 2) it was found that the treatment T5 and T6 had higher puncture resistance than the other treatment. From these results it was observed that CFB boxes fabricated with 200GSM thick kraft paper had higher puncture resistance as compared to those made from 180GSM thick kraft paper.

\section{Testing of customised corrugated fibre board box fabricated for sapota packaging}

The CFB boxes designed was tested by packing with sapota (Cv. Cricket Ball) (approx.3.5-4kg) in the boxes as treatment T1(5ply, 180GSM, 18BF), T2-(5ply, 180GSM, 20BF), T3-(5ply, 180GSM, 22BF), T4-(3ply, 200GSM, 18BF), T5-(3ply, 200GSM, 20BF), T6-(3ply, 200GSM, 22BF). The boxes were subjected to drop test from a height of about $1 \mathrm{~m}$ from the ground level. The boxes with sapota were then stored at low temperature $\left(15^{\circ} \mathrm{C}, \mathrm{RH} 85 \%\right)$ and ambient temperature $\left(26^{\circ} \mathrm{C}, \mathrm{RH} 46.2 \%\right)$. The boxes were subjected to drop test from a height of about $1 \mathrm{~m}$ from the ground level. The boxes with sapota were then stored at low temperature $\left(15^{\circ} \mathrm{C}, \mathrm{RH}\right.$ $85 \%)$ and ambient temperature $\left(26^{\circ} \mathrm{C}, \mathrm{RH}\right.$ $46.2 \%$ ). From the studies it was found that except treatment $\mathrm{T} 5$, all the other treatments 
withstood the drop test. The CFB box (T1) was found suitable as there was no bend or bulge on the top and sides were observed when stored at low temperature. The moisture absorption by the box was $6.7 \%$ (T1) at the end of the storage period of 16 days. The damage $(\%)$ of the fruit was $2 \%$ which was lower compared to other treatment.

Weight loss (\%) and spoilage (\%) of sapota during storage in fabricated customised CFB boxes

The weight loss of sapota packed in 3 ply CFB box and stored at ambient temperature storage was higher than those packed in 5 ply CFB box and stored at low temperature.

The fruit spoilage (\%) ranged from $1.72 \%$ to $10.2 \%$ at the end of the storage period of 16 days at low temperature (Fig. 1a) compared to spoilage 13.2 to $18.52 \%$ (Fig. 1b) at ambient temperature at the end of the storage period of 11 days. Hence, the percentage marketability of sapota stored in low temperature storage was higher than those stored under ambient

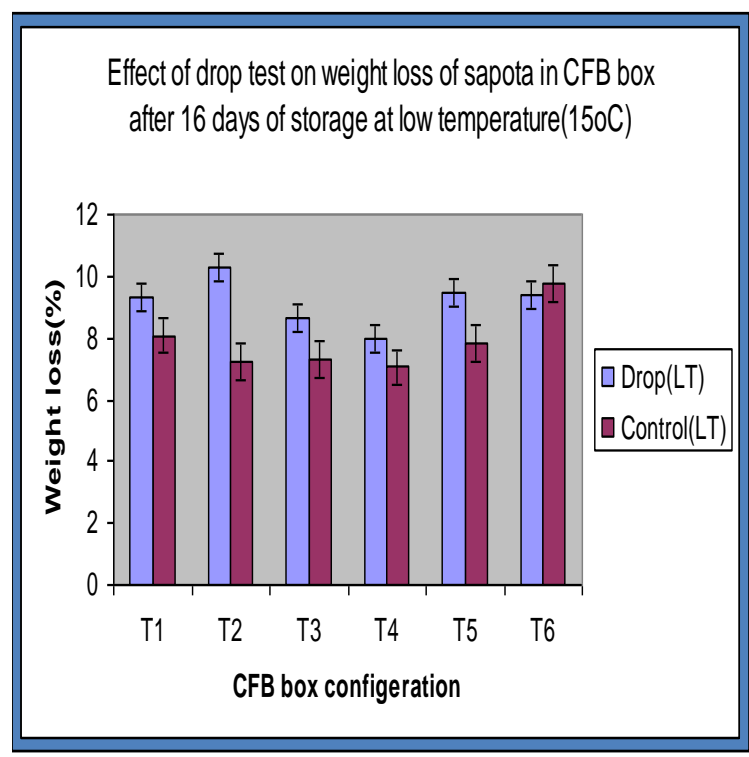

Fig.1a. Effect of drop test on weight loss of sapota at low temperature storage $\left(15^{\circ} \mathrm{C}, 85 \% \mathrm{RH}\right)$ condition. Similar results were reported for papaya by Azene et al., (2011)

\section{Total soluble solids}

The changes in total soluble solids (TSS) content of sapota fruits during the storage both in low temperature storage and ambient condition is given in table $2 \mathrm{a}$ and $2 \mathrm{~b}$. The TSS values of fruits varied between 15.0-17.46 Brix in ambient storage and from 16.13$18.53^{\circ}$ Brix under low temperature storage. The fruits stored in CFB box of 18BF strength had lower TSS content compared to those in $20 \mathrm{BF}$ and $22 \mathrm{BF}$ strength in both storage conditions.

\section{Acidity}

In this study, the titrable acidity value varied from $0.24-0.36$ in the low temperature storage and $0.17-0.25 \%$ under ambient storage conditions, respectively (Table $2 \mathrm{a}$ and $2 \mathrm{~b}$ ). The effect of CFB box packaging and storage environment had no significant effect on the acidity of sapota fruits.

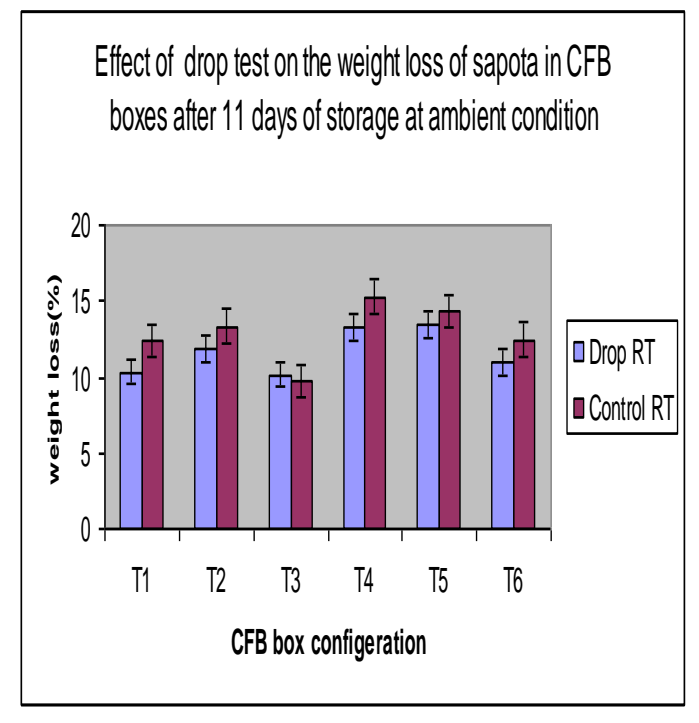

Fig.1b Effect of drop test on weight loss of sapota at ambient temperature storage $\left(28-30^{\circ} \mathrm{C}, 55 \% \mathrm{RH}\right)$ 
Table.1 Cobb value and puncture resistance of CFB boxes of different ply rate and bursting strength

\begin{tabular}{|c|c|c|c|c|c|c|}
$\begin{array}{c}\text { Treatmen } \\
\text { ts }\end{array}$ & $\begin{array}{c}\text { Box } \\
\text { Dimension } \\
(\mathrm{mm})\end{array}$ & $\begin{array}{c}\text { Kraft paper } \\
\text { thickness } \\
(\mathrm{Gsm})\end{array}$ & Ply rate & $\begin{array}{c}\text { Box } \\
\text { strength } \\
(\mathrm{BF})\end{array}$ & $\begin{array}{c}\text { Cobb } \\
\text { value }\left(\mathrm{g} / \mathrm{m}^{2}\right)\end{array}$ & $\begin{array}{c}\text { Puncture } \\
\text { Resistance } \\
\left(\mathrm{N} / \mathrm{m}^{2}\right)\end{array}$ \\
\hline T1 & $400 \times 300 \times 100$ & 180 & 5 & 18 & 14.24 & 85.46 \\
\hline T2 & $400 \times 300 \times 100$ & 180 & 5 & 20 & 12.42 & 82.86 \\
\hline T3 & $400 \times 300 \times 100$ & 180 & 5 & 22 & 15.52 & 84.04 \\
\hline T4 & $400 \times 300 \times 100$ & 200 & 3 & 18 & 9.64 & 85.22 \\
\hline T5 & $400 \times 300 \times 100$ & 200 & 3 & 20 & 15.89 & 93.72 \\
\hline T6 & $400 \times 300 \times 100$ & 200 & 3 & 22 & 16.21 & 93.72 \\
\hline
\end{tabular}

Table.2a Bio chemical quality of sapota in CFB box at the end of the storage period at ambient condition $\left(28-30^{\circ} \mathrm{C}, 55 \% \mathrm{RH}\right)$

\begin{tabular}{|c|c|l|l|l|}
\hline Treatment & $\begin{array}{c}\text { TSS } \\
\left({ }^{(\mathbf{B r i x})}\right.\end{array}$ & $\begin{array}{c}\text { Acidity } \\
(\boldsymbol{\%})\end{array}$ & $\begin{array}{c}\text { Reducing } \\
\text { Sugar }(\mathbf{\%})\end{array}$ & $\begin{array}{c}\text { Total } \\
\text { sugar } \\
(\mathbf{\%})\end{array}$ \\
\hline T1 & 17.23 & 0.32 & 13.64 & 16.58 \\
\hline T2 & 17.46 & 0.25 & 13.24 & 16.35 \\
\hline T3 & 16.87 & 0.34 & 13.87 & 15.65 \\
\hline T4 & 16.07 & 0.25 & 13.39 & 15.74 \\
\hline T5 & 17.07 & 0.36 & 14.25 & 16.85 \\
\hline T6 & 15.53 & 0.24 & 12.26 & 14.45 \\
\hline CD (5\%) & 0.22 & 0.09 & 0.51 & 0.65 \\
\hline
\end{tabular}

Table.2b Biochemical quality of sapota in CFB box at the end of the storage period at low temperature storage $\left(15^{\circ} \mathrm{C}, \mathrm{RH} 85 \%\right)$

\begin{tabular}{|c|c|c|c|c|}
\hline Treatment & $\begin{array}{c}\text { TSS } \\
\left({ }^{\mathbf{D}} \mathbf{B r i x}\right)\end{array}$ & $\begin{array}{c}\text { Acidity } \\
(\mathbf{\%})\end{array}$ & $\begin{array}{c}\text { Reducing } \\
\text { Sugar }(\mathbf{\%})\end{array}$ & $\begin{array}{c}\text { Total sugar } \\
(\mathbf{\%})\end{array}$ \\
\hline $\mathrm{T} 1$ & 17.2 & 0.25 & 12.05 & 16.07 \\
\hline $\mathrm{T} 2$ & 16.13 & 0.17 & 13.10 & 16.71 \\
\hline $\mathrm{T} 3$ & 17.43 & 0.17 & 12.54 & 16.81 \\
\hline $\mathrm{T} 4$ & 16.73 & 0.21 & 13.02 & 16.02 \\
\hline $\mathrm{T} 5$ & 17.87 & 0.23 & 15.65 & 16.96 \\
\hline T6 & 18.53 & 0.20 & 13.94 & 16.96 \\
\hline $\mathrm{CD}(5 \%)$ & 0.21 & NS & NS & 0.75 \\
\hline
\end{tabular}




\section{Reducing sugars}

The effect of storage condition and CFB box packaging material combination on reducing sugar content of sapota fruit at the end of the storage period is given in Table $2 \mathrm{a}$ and $2 \mathrm{~b}$. The reducing sugar concentration varied from 12.26-14.25(\%) of fresh weight for sapota stored in ambient condition whereas the concentration varied from 12.54-14.25 (\%) for those stored in low temperature storage. There was no significant effect on the reducing sugars content of sapota in CFB boxes of different packaging combinations.

\section{Total sugars}

The effect of storage condition and CFB box packaging material on total sugar content of sapota fruit at the end of the storage period is given in Table $2 \mathrm{a}$ and $2 \mathrm{~b}$. The total sugar content varied from 14.45-16.85 (\%) of fresh weight for sapota stored in ambient condition whereas the total sugar content varied from 16.02-16.96 (\%) for those stored in low temperature storage. The total sugar content of the fruits at low temperature storage was higher than the total sugar content of papayas stored in ambient condition. This could be associated with the higher rates of respiration and metabolic activity resulting in rapid hydrolysis of sugar under ambient temperature (Ramakrishnan et al., 2010). According to Willey (1994), higher temperature favours faster sugar utilisation as substrate in the respiration process. The relatively lower temperature in the cold storage helped to preserve the total sugar of the fruits possibly through retarding respiration and thus delaying ripening (Wang, 1989).

\section{Shelf life}

The shelf life of sapota was 11 days at ambient storage $\left(28-30^{\circ} \mathrm{C}, \quad 55 \% \quad \mathrm{RH}\right)$ conditions. The termination of shelf life of sapota stored at ambient environment was determined by shrivelling, over ripening, discoloration and mould growth. Faster transpiration rate at relatively higher temperature may result in shrivelling of sapota fruits in ambient storage condition. Furthermore, higher respiration rate at higher temperature may lead to senescence because the stored food reserve which provides energy could be exhausted (Paull 1993).

Sapota stored in the low temperature storage remained fresh and firm upto 16 days of storage. The ripening rate was also delayed in low temperature storage. Since a higher rate of respiration decreases shelf life (Lee et al., 1995), the use of low temperature is indicated to be the most important means of extending the storage life of postharvest produce (Exama et al., 1993).

Packaging plays an important role on the shelf life and quality of sapota fruits. In this experiment, CFB boxes of size $400 \times 300 \times 100 \mathrm{~mm}, 5$ ply rate with $20 \mathrm{BF}$ bursting strength and maintained at temperature $15^{\circ} \mathrm{C}$, and relative humidity $80 \%$ $\mathrm{RH}$ is found to be suitable for storage of sapota. The fruits packaged in these boxes withstood drop test, had less weight loss, less spoilage and had a shelf life of 11 days in ambient condition and 16 days in low temperature storage.

\section{References}

Azene M, Workneh TS, Woldetsadik K. 2011. Effects of different packaging materials and storage environment on postharvest quality of papaya fruit. $J$. Food Sci. Technol. DOI 10.1007/s 13197-011-0607-6.

Bhuvaneswari, S and C.K. Narayana. 2013. Evaluation of different types of Packages for Road Transportation of 
papaya. International Journal of Innovative Horticulture 2(1): 95-98.

Djilali Hammou, A., Minh Duong, P. T., Abbes, B., Makhlouf, M., and Guo, Y. Q. 2012. Finite-element simulation with a homogenization model and experimental study of free drop tests of corrugated cardboard packaging. Mechanics \& Industry 13(03): 175-184.

Exama A, Arul J, Lencki R and Li Z1993. Suitability of various plastic films for modified atmosphere packaging of fruits and vegetables: Gas transfer properties and effect of temperature fluctuation. Acta Hort. 1993; 343:175180.

IS 13228 2006. Corrugated fibreboard boxes for packing and transportation. Bureau of Indian Standard, New Delhi.

ISO 2247. Packaging - Complete, filled transport packages and unit loads Vibration tests at fixed low frequency. International Organization for Standardization, Geneva, Switzerland

ISO 8318. Packaging - Complete, filled transport packages - Sinusoidal vibration tests using a variable frequency. International Organization for Standardization, Geneva, Switzerland
Lee L, Arul J, Lencki $\mathrm{R}$ and Castaigne F.1995. A review on modified atmosphere packaging and preservation of fresh fruits and vegetables. Physiological basis and practical aspects, Part-1, Pack. Technol. Sci. 8: 315-331

Paull RE.1993. Pineaple and papaya. In: Symour GB, Taylor JE and Tucker GA (eds.). Biochemistry of fruit ripening. Chapman and Hall, New York, Tokyo pp. 291-311.

Ramakrishnan K, Narayanan P, Vasudevan V, Muthukumaran G and Antony U. 2010 Nutrient composition of cultivated stevia leaves and the influence of polyphenols and plant pigments on sensory and antioxidant properties of leaf extracts. J Food Sci Technol. 47(1):27-33.

Ranganna S.2000. Manual of Analysis of Fruit and Vegetable Products. Tata McGraw-Hill Publishing Co. Ltd., New Delhi. Second Ed, pp10.

Wang CV. 1989.Chilling injury of fruits and vegetables. Food Rev Int. 5: 209-236. doi: 10.1080/87559128909540850

Willey RC. 1994. Minimally processed refrigerated fruits and vegetables. New York: Chapman and Hall.

\section{How to cite this article:}

Bhuvaneswari, S. and Sudhakar Rao, D.V. 2018. Development of Customized Corrugated Fibre Board Boxes for Sapota Packaging. Int.J.Curr.Microbiol.App.Sci. 7(03): 2959-2965. doi: https://doi.org/10.20546/ijcmas.2018.703.342 